\title{
Debunking the Stereotype of
} the Lazy Welfare Recipient: Evidence from Cash Transfer Programs Worldwide Faculty Research Working Paper Series

\section{Abhijit Banerjee}

Massachusetts Institute of Technology

Rema Hanna

Harvard Kennedy School

\section{Gabriel Kreindler}

Massachusetts Institute of Technology

\section{Benjamin A. Olken}

Massachusetts Institute of Technology

\section{December 2015 \\ RWP15-076}

Visit the HKS Faculty Research Working Paper Series at:

https://research.hks.harvard.edu/publications/workingpapers/Index.aspx

The views expressed in the HKS Faculty Research Working Paper Series are those of the author(s) and do not necessarily reflect those of the John F. Kennedy School of Government or of Harvard University. Faculty Research Working Papers have not undergone formal review and approval. Such papers are included in this series to elicit feedback and to encourage debate on important public policy challenges. Copyright belongs to the author(s). Papers may be downloaded for personal use only. 


\title{
Debunking the Stereotype of the Lazy Welfare Recipient:
}

\section{Evidence from Cash Transfer Programs Worldwide}

\author{
Abhijit Banerjee, Rema Hanna, \\ Gabriel Kreindler, and Benjamin A. Olken
}

CID Working Paper No. 308

October 2015

(C) Copyright 2015 Banerjee, Abhijit; Hanna, Rema; Kreindler, Gabriel; Olken, Benjamin A.; and the President and Fellows of Harvard College at Harvard University 


\title{
Debunking the Stereotype of the Lazy Welfare Recipient: Evidence from Cash Transfer Programs Worldwide ${ }^{1}$
}

\author{
Abhijit Banerjee, MIT \\ Rema Hanna, Harvard \\ Gabriel Kreindler, MIT \\ Benjamin A. Olken, MIT
}

\begin{abstract}
Targeted transfer programs for poor citizens have become increasingly common in the developing world. Yet, a common concern among policy makers - both in developing as well as developed countries - is that such programs tend to discourage work. We re-analyze the data from 7 randomized controlled trials of government-run cash transfer programs in six developing countries throughout the world, and find no systematic evidence that cash transfer programs discourage work.
\end{abstract}

\section{INTRODUCTION}

Governments in the developing world are increasingly providing social assistance programs for their disadvantaged citizens. For example, in a recent review of programs worldwide, Gentilini et al (2014) find that 119 developing countries have implemented at least one type of unconditional cash assistance program and 52 countries have conditional cash transfer programs for poor households. Thus, on net, they find that 1 billion people in developing countries participate in at least one social safety net. ${ }^{2}$

\footnotetext{
1 Contact email: bolken@mit.edu or rema hanna@hks.harvard.edu. We thank Alyssa Lawther for excellent research assistance. This study would not have been possible without the many researchers who provided their data to us (or to the public-at-large) and we thank them wholeheartedly for their efforts. All of the views expressed in the paper are those of the authors, and do not necessarily reflect the views any of the many institutions or individuals acknowledged here.

${ }^{2}$ Note that this includes both in-kind and cash transfer programs.
} 
These programs serve to transfer funds to low-income individuals and have been shown to have led to reductions in poverty (Fiszbein and Schady 2009) and to have positive effects on education (Schultz 2004, Glewwe and Olinto 2004, Maluccio and Flores 2005) and health services (Gertler 2000, Gertler 2004, Attanasio et al. 2005). However, despite this, policy-makers are often concerned about whether transfer programs of this type discourage work. And indeed, in developed country policy contexts, some transfer programs have indeed been shown to have small, but statistically significant, effects on work. ${ }^{3}$ On the other hand, despite occasional claims in policy circles to the contrary, there is little rigorous evidence showing that transfer countries in poor countries actually lead to less work, with most existing evidence finding little or no effect of transfer programs on labor supply (see, for example, Alzua, Cruces, and Ripani, 2013; Parker and Skoufias, 2000).

In this paper, we re-analyze the results of seven randomized controlled trials of government run cash transfer programs from six countries worldwide to examine the program impacts on labor supply. ${ }^{4}$ Re-analyzing the data allows us to make comparisons that are as comparable as possible, using harmonized data definitions and empirical strategies. Reanalyzing the micro data directly also allows us to pool effects across studies to yield tighter bounds than would be possible from any single study.

In this paper we bring together data on this issue from the randomized control trials (RCT) that we could find that met three criteria: ${ }^{5}$ it was an evaluation of a (conditional or unconditional) cash transfer program in a low-income country that compared the program to a

\footnotetext{
${ }^{3}$ See for example, Ashenfelter and Plant (1990) analysis of the Seattle -Denver Maintenance Experiment or Imbens, Rubin, Sacerdote (2001) estimates of the effect of unearned income on work from studying lottery winners.

${ }^{4}$ This extends Alzua, Cruces, and Ripani (2013), which explores the program impacts on labor outcomes for three of the programs that we include. While we use slightly different specifications to harmonize across the full set of datasets that we include, our findings echo theirs.

5 This is a work in progress and we are still continuing to accumulate datasets from additional RCTs that fit these criteria.
} 
pure control group; we could obtain micro data for both adult males and females from the evaluation; and the randomization needed to have at least 40 clusters (more details on these restrictions can be found below). To date, this yielded data for programs from six countries: Honduras, Indonesia, Morocco, Mexico (2 different programs), Nicaragua, and the Philippines.

Across the seven programs, we find no observable impacts of the cash transfer programs on either the propensity to work or the overall number of hours worked, for either men or women. Pooling across the five comparably designed studies to maximize our statistical power to detect effects if they exist, we again find no observable impacts on either work outcome.

Theoretically, the transfers could have different effects on work outside the household versus self-employment or work within the family. For example, one could imagine that the effect for outside work sector may be larger, as individuals fear-rationally or otherwise-that formal work employment could disqualify them from receiving future transfers. Looking at

the pooled sample, we find a small, significant negative effect on work inside the household (about 1 percentage point, significant at 10 percent level). However, we find no observable effect of the transfers on work outside the household (if anything, while statistically insignificant, the estimated treatment effect is positive).

In short, despite much of the rhetoric that cash transfer programs lead to a massive exodus from the labor market, we do not find overwhelming evidence to support these claims.

\section{DATA, EMPIRICAL STRATEGY AND SAMPLE STATISTICS}

In this section, we first describe the data and then detail our empirical strategy. In the last subsection, we provide sample statistics to provide a descriptive picture of each program area. 


\section{A. DATA AND PROGRAM DESCRIPTION}

We began by identifying randomized evaluations of cash transfer programs in low-income nations. For a study to be included, it needed to have both a pure control group and at least one treatment arm of a conditional or unconditional cash transfer program. In several of the studies that we identified, the authors had randomized across different variants of a cash transfer program or compared cash to in-kind transfers, but did not have a pure control group. These studies provide us with valuable information about how outcomes change based on the program design features, but do not provide us with the overall effect of having the program to begin with and thus are excluded from our analysis.

In total, to date, we identified 18 RCTs that met the above criteria. ${ }^{6}$ of these, three were excluded because they did not include variables on both male and female adult labor supply in the public datasets, ${ }^{7}$ two were excluded due to having fewer than 40 clusters, ${ }^{8}$ and to date we have been unable to obtain data for another six studies. ${ }^{9}$

Therefore just 7 RCTs were included in this analysis: Honduras' PRAF II, Morocco's Tayssir, Mexico's Progresa and PAL, Philippines' PPPP, Indonesia's PKH, and Nicaragua's RPS. A notable characteristic of all 7 programs is that they are implemented by national governments (as opposed to NGOs) either as pilot or expansion programs, and thus are

\footnotetext{
${ }^{6}$ We apologize in advance if we have missed a particular study that meets our criterion. Please contact us if you believe we have omitted a potential RCT from this list.

${ }^{7}$ Ecuador's BDH (Edmonds and Schady, 2012; Schady and Caridad Araujo, 2008), Columbia's SCAE (BarreraOsorio et al, 2011), and Nicaragua's Atención a Crisis (Macours et al, 2012).

8 Treatment status was randomized over 8 communities in Malawi's SCT program (Covarrubias et al, 2012) and over 28 locations in Kenya's CT-OVC. Despite having a larger number of households in both experiments, the small number of randomization units biases one towards not being able to measure a statistically significant effect unless the effect size is very large; therefore, we did not include them.

9 These include Kenya's Give Directly (Haushofer and Shapiro, 2013), Tanzania's TASAF (Evans, Hausladen, Kosec, and Reese, 2014), Burkina Faso's NCTPP (Akresh, De Walque and Kazianga, 2013), Uganda's cash transfer to pre-schools (Gilligan and Roy, 2013), Zambia's Child Program (American Institute for Research 2013) and the Malawi - Schooling, Income, and Health Risk Impact Evaluation Household Survey (Baird, McIntosh, and Ozler, 2011). Some of these datasets are not publicly available and thus cannot be included in our analysis. Others we are in the process are acquiring and we hope to include in future paper drafts.
} 
Figure 1: Summary of Included Studies

\begin{tabular}{|c|c|c|c|c|c|c|}
\hline Country & Program & $\begin{array}{c}\text { Evaluation } \\
\text { Years }\end{array}$ & $\begin{array}{l}\text { Number of } \\
\text { Households } \\
\text { at Endline } \\
\end{array}$ & Targeting Method & Transfer Type and Amount & $\begin{array}{c}\text { Transfer/ } \\
\text { Consumption }\end{array}$ \\
\hline Honduras & $\begin{array}{c}\text { Programa de } \\
\text { Asignación } \\
\text { Familiar - Phase II } \\
\text { (PRAF II) }\end{array}$ & $2000-2002$ & 3,265 & $\begin{array}{c}\text { Geographic and family } \\
\text { demographics }\end{array}$ & $\begin{array}{l}\text { CCT ranging from } \$ 4 \text { to } \$ 23 \text { per } \\
\text { month depending on family } \\
\text { structure }\end{array}$ & $4 \%$ \\
\hline Morocco & Tayssir & $2008-2010$ & 4,277 & Geographic & $\begin{array}{l}\text { CCT and labelled CCTs: between } \$ 8 \\
\text { to } \$ 13 \text { per month per child } \\
\text { (depending on age of child) }\end{array}$ & $5 \%$ \\
\hline Mexico & Progresa & 1998-1999 & 20,908 & Geographic and PMT & $\begin{array}{c}\text { CCT: } \$ 12.5 / \text { month }+\$ 8- \\
\$ 30.5 / \text { month per child (depends on } \\
\text { child grade) }+\$ 11-\$ 20.5 \text { grant for } \\
\text { school materials per child, } \\
\text { Max grant per HH }(1999): \\
\$ 75 / \text { month }\end{array}$ & $20 \%$ \\
\hline Mexico $^{1}$ & $\begin{array}{c}\text { Programa de } \\
\text { Apoyo Alimentario } \\
\text { (PAL) }\end{array}$ & 2004-2005 & 2,986 & Geographic & UCT: $\$ 13$ per month & $11.50 \%$ \\
\hline Phillipines & $\begin{array}{c}\text { Pantawid } \\
\text { Pamilyang Pilipino } \\
\text { Program (PPPP) }\end{array}$ & $2009-2011$ & 1,418 & Geographic and PMT & $\begin{array}{c}\text { CCT: } \$ 11-\$ 30 \text { per month depending } \\
\text { on number of kids }\end{array}$ & $11 \%$ \\
\hline Indonesia & $\begin{array}{l}\text { Program Keluarga } \\
\text { Harapan (PKH) }\end{array}$ & 2007-2009 & 14,750 & Geographic and PMT & CCT: $\$ 44-\$ 161$ per year & $17.50 \%$ \\
\hline Nicaragua & $\begin{array}{l}\text { Red de Protección } \\
\text { Social (RPS) }\end{array}$ & $2000-2002$ & 1,397 & $\begin{array}{c}\text { Geographic. All except } \\
6 \% \text { who owned } \\
\text { vehicle or } \geq 14 \text { ha land }\end{array}$ & $\begin{array}{l}\text { CCT: } \$ 224 / \text { year }+\$ 112 / \text { year } \\
\text { (school attendance) + } \\
\$ 21 / \text { child/year }\end{array}$ & $20 \%$ \\
\hline
\end{tabular}

Notes: (1) The experiment included two treatments: a food transfer and a cash transfer. We focus on the cash transfer treatment only.

Sources: Honduras: Galiani and McEwan (2013), Glewwe and Olinto (2004); Morocco: Benhassine, Devoto, Duflo, Dupas, and Pouliquen (2015); Mexico Progresa: Parker and Skoufias (2000); Skoufias and di Maro (2008); Mexico PAL: Skoufias, Unar, and Gonzalez-Cossio (2013); Philipinnes: Chaudhury, Friedman and Onishi (2013); Indonesia: World Bank Office Jakarta (2011); Nicaragua: Maluccio and Flores (2005) 
representative of "real-world" cash transfers. Figure 1 provides some summary details about the programs and evaluation data and provides references to key academic papers for each program.

In terms of program type, most of the programs that we include are conditional cash transfer (CCTs), where benefits are "conditional" on desirable social behaviors, such as ensuring your children attend school and get vaccinated. The two exceptions to pure CCT programs were: (1) Mexico's PAL program, where benefits were not conditioned on behaviors ${ }^{10}$ and (2) Morocco's Tayssir program, which had two treatment arms consisting of a CCT and a "labeled" cash transfer in which the conditions were recommended but were explicitly not enforced. In general, it is important to note that there is considerable variation in how stringent conditions are enforced across countries, so even in programs that profess conditionality, beneficiaries may still receive the full stipend amount regardless of whether they meet them.

A first challenge in these types of programs is finding the poor ("targeting"). Unlike developed countries, where program eligibility can be verified from tax returns or employment records, developing country labor markets often lack formal records on income and employment and thus alternative targeting methods must be used (see Alatas, et al, 2012, for a description). For all of the programs in our study, regions were first geographically targeted based on some form of aggregate poverty data. After that, in 5 out of the 7 programs eligibility was determined by a demographic criterion (e.g. a woman in the household was pregnant or there were children below an age cutoff) and/or an asset-based means test (e.g. not owning land over a certain size).

${ }^{10}$ Mexico's PAL program also had an in-kind treatment, which we do not utilize for this analysis. 
Once a household becomes eligible for any of the programs that we study, the amount of benefit that one receives is the same regardless of actual income level and lasts at least a period between 2 and 9 years, depending on the program. This differs from many U.S. transfer programs (e.g. EITC, SNAP), where the stipend depends (either positively or negatively) on family income, and is updated frequently. This discrepancy likely stems from the greater difficulty in ascertaining precise income levels in data-poor environments. However, similar to the U.S programs, the level of the transfer received was determined, at least in part, by the number of children in the family and their ages. On net, however, the programs were fairly generous ranging from 4 percent of household consumption (Honduras' PRAF II) to about 20 percent (Mexico’s Progresa).

For each evaluation, we obtained the raw evaluation micro-datasets from either online downloads or personal correspondence with the authors. Note two features of the evaluation design that affects the analysis. First, all of the studies that we consider are clusteredrandomized designs, i.e. the program was randomized over locations rather than individuals. Thus, in the analysis below, we cluster our standard errors by the randomization unit. Second, we have both baseline and endline data for 5 of the studies. Baseline data were not collected for the Philippines' PPPP. Moreover, the baseline data for the treatment group of the Honduras' PRAF II study was collected in a different agricultural season than for the control group (Glewwe and Olinto 2004). Alzua, Cruces, and Ripani (2013) point out that this leads a small but statistically significant imbalance in labor supply between the two groups and, therefore, we decided not to use the baseline for this program. Thus, as we discuss below, we use a different empirical strategy for the programs with baseline data and those without.

While some of the studies had explored impacts on some of the work variables, the sample composition and work variable definitions varied across the studies. Thus, we 
harmonized the datasets. First, we attempted to restrict our datasets to include all adult males and females, aged 16 to 65, from eligible households. We have two exceptions to this, where we included adults in all surveyed households (regardless of eligibility status): First, Nicaragua's RPS contains a random sample of households. About 6 percent of households were excluded from the cash transfer program based on a proxy means test, but we cannot identify them in the data. Second, Honduras' PRAF II has a random sample from households in the geographically targeted areas; we attempted to code the eligibility rules within the evaluation dataset, but did not yet feel fully confident in our ability to back out eligible households.

Next, for these samples, we coded consistent variables for employment status and hours worked per week for each included individual. ${ }^{11}$ Note two important features of our data setup: First, our sample includes all individuals, regardless of whether or not they are in the labor force. Thus, if cash transfers induce individuals to exit the labor force, this will be captured by our employment variable. Similarly, individuals who are do not work are counted as "zero" hours of work in our analysis; thus, this variable is capturing both the decision to work (extensive margin) and the number of hours worked (intensive margin). Second, we lack information on hours of work for Indonesia's PKH program, so it is only included in the analysis on employment status.

In the poor areas where the programs that we analyze are located, a significant share of people work in agriculture (in rural areas) or in self-employment. We include both these activities in the employment status, and we later analyze two outcome variables that differentiate between household work (any self-employed activity) and work outside the household (casual or permanent employment).

${ }^{11}$ All programs except Morocco ask about the number of hours worked during the last week. In Morocco the reference period is the last 30 days, and we normalize the response by $7 / 30$. 


\section{B. EMPIRICAL STRATEGY}

We begin our analysis by first estimating the effect of being randomized to receive a transfer program on labor market outcomes. Due to the randomization of who received the program, the treatment and control groups should be similar on average, except for receiving the program. Thus, one can estimate the following regression:

$$
\text { Eq 1: } \quad y_{i c}=\text { Breat }_{c}+\mu_{s(c)}+\boldsymbol{\gamma} \cdot \boldsymbol{X}_{i c}+\varepsilon_{i c}
$$

where $i$ is an individual in cluster (randomization unit) $c . \quad y_{i c}$ is individual $i$ 's labor market outcome, either an indicator variable that takes the value of 1 if the individual is employed or a continuous variable on the hours an individual worked per week. Treat ${ }_{c}$ is an individual variable that equals 1 if individual was randomly assigned to the treatment group and zero otherwise; $\beta$ is the parameter of interest, providing the difference in work outcomes between the treatment and the control group.

Note two features of the specification. First, while the randomization should ensure that $\beta$ capture the causal impact of the program, we can include additional control variables to improve our statistical precision. Specifically, we include strata fixed effects $\left(\mu_{s(c)}\right)$ and a number of individual-level control variables $\left(\boldsymbol{\gamma} \cdot \boldsymbol{X}_{i c}\right)$, including age, age squared, household size, years of education, and a dummy variable for being married or in a partnership. For each control variable, we code missing values at the variable mean and include a dummy variable that indicates the observations with missing values. Standard errors are clustered at the randomization unit level.

We run this basic specification for the two programs for which we do not have reliable baseline data (Philippines' PPPP and Honduras' PRAF II). For the other 5 programs, we can take advantage of the fact that baseline data were also collected. Specifically, we can stack the 
individual baseline and endline data and estimate the following difference-in-difference specification:

$$
\text { Eq2: } y_{i c t}=\text { Treat }_{c}+\mu_{s(c)}+\text { Post }_{t}+\beta\left(\text { Treat }_{c} \times \text { Post }_{t}\right)+\boldsymbol{\gamma} \cdot \boldsymbol{X}_{i c t}+\varepsilon_{i c t}
$$

where $i$ is an individual in cluster $c$ at time $t$. While the randomization implies that Equation 1 would provide a causal estimate of the program effect, the difference-in-difference specification allows us to better control for any baseline imbalances between the treatment and control group and thus provides us with greater statistical precision. ${ }^{12}$ We include all of the same control variables as before and continue to cluster our standard errors at the randomization unit.13 The parameter of interest is $\beta$, which provides the difference in work outcomes across the treatment and control relative to their baseline values and conditional on our control variables.

A benefit of harmonizing and re-analyzing the various micro-datasets is that we can pool the data across studies and estimate a single treatment effect. This allows us to potentially generate tighter statistical bounds than would be possible from any one study. For the five studies for which we have baseline data available, we additionally estimate the following pooled difference-in-difference specification:

Eq 3: $y_{i c p t}=$ Treat $_{c p}+\mu_{s(c p)}+$ Post $_{t}+\eta_{p} \times$ Post $_{t}+\beta$ Treat $_{c p} \times$ Post $_{t}+\boldsymbol{\gamma}_{\boldsymbol{p}} \cdot \boldsymbol{X}_{\text {icpt }}+\varepsilon_{\text {icpt }}$ where $p$ now identifies which program evaluation the individual belongs to. We include the same control variables as before, but we now interact them with indicator variables for each program. As the sample sizes vary considerably across studies, the observations are weighted

\footnotetext{
12 We can additionally estimate Equation 1 for these five programs. The findings remain the same, with no observable effects on employment, except Mexico's Progresa, where we actually find a slightly positive effect of the transfer programs on employment.

13 There are two additional differences across specifications. First, as Mexico's Progresa includes three endline waves and Nicaragua's RPS has two endline waves, we additionally include wave dummy variables in these specifications. Second, we weight observations in Morocco's Tayssir to account for the sampling structure as in Benhassine, Devoto, Duflo, Dupas, and Pouliquen (2015).
} 
such that each program receives equal weight; we continue to cluster the standard errors by the randomization unit level. $\beta$ is again our parameter of interest, but now captures the effect of the transfers across all five programs under consideration.

\section{SAMPLE STATISTICS}

Table 1 provides descriptive statistics for the standardized work variables that we construct across the seven studies, using data from the control group to show work outcomes in the absence of the program. ${ }^{14}$

Many of the program recipients would have worked in the absence of the program. Preprogram employment ranged from 40 percent in Morocco to 61 percent in Indonesia, with a weighted mean of 53 percent across all programs. Note that this figures includes all adults aged 16 to 65, including those not in the labor force due to being in school, disability, or retirement. Across everyone regardless of employment status, we observe about 20 hours of work per week, implying about a 40 hour work week for those who are employed.

However, these means mask considerably heterogeneity in work patterns. First, male employment rates are high, with a weighted average of about 86 percent; in contrast, female employment rates tend to be much lower, ranging from 5 percent in Morocco to 39 percent in Indonesia. Second, for most countries, work outcomes tend to be split between selfemployment/family work and outside work, with two key exceptions: men in Honduras tend to be more engaged in work inside the house, while men in Mexico's Progresa program tend to be more engaged in outside work.

\footnotetext{
${ }^{14}$ Note that we provide the control group statistics rather than the baseline since we do not have baseline data for two of the programs and the definitions of work are not the same in the baseline and endline for one of the evaluations (Morocco's Tayssir).
} 


\section{DO CASH TRANSFERS REDUCE WORK?}

\section{A. OVERALL FINDINGS}

Figure 2 provides a graphical summary of our main findings. In Figure 2A, we graph the employment rate for all eligible adults in both the control and treatment arms for each evaluation. Note that the evaluations are listed in order from the least generous in terms of benefits relative to consumption levels (Honduras' PRAF) to the most generous (Nicaragua's RPS and Mexico's Progresa). Figure 2B replicates Figure 1A, but for hours of work. As one can see by just looking across each program, the overall figures for both employment and hours of work are similar across treatment and control across all of the programs.

Table 2 provides the corresponding regression analysis underlying Figure 2. Panel A presents the analysis for the employment outcome, while Panel B does so for hours of work per week. Columns 1 through 7 present the analysis for each individual program, while Column 8 provides the pooled analysis for the five programs in which baseline data are also available.

As Figure 2 showed, we do not observe a significant effect of belonging to a transfer program on employment or hours of work in any of the seven programs. Turning to the pooled estimates in Column 8, we also cannot distinguish the effect of the program from zero. These insignificant results are not just driven by large standard errors, as the estimated magnitudes of the pooled treatment effects are, in fact, very small. For example, the coefficient on employed is -.003 , representing a statistically insignificant 0.58 percent (i.e., about one half of one percent) relative to the control group of 53 percent (p-value of 0.59). The 95\% confidence interval on this estimate is between a 1.4 percentage point decrease and a 0.8 percentage point increase in the employment probability.

In Table 3, we disaggregate work type by whether the work is self-employed/within family (Panel A) or outside of the household (Panel B). This is especially important if we 
Figure 2: Experimental Estimates of Cash Transfers on Work outcomes
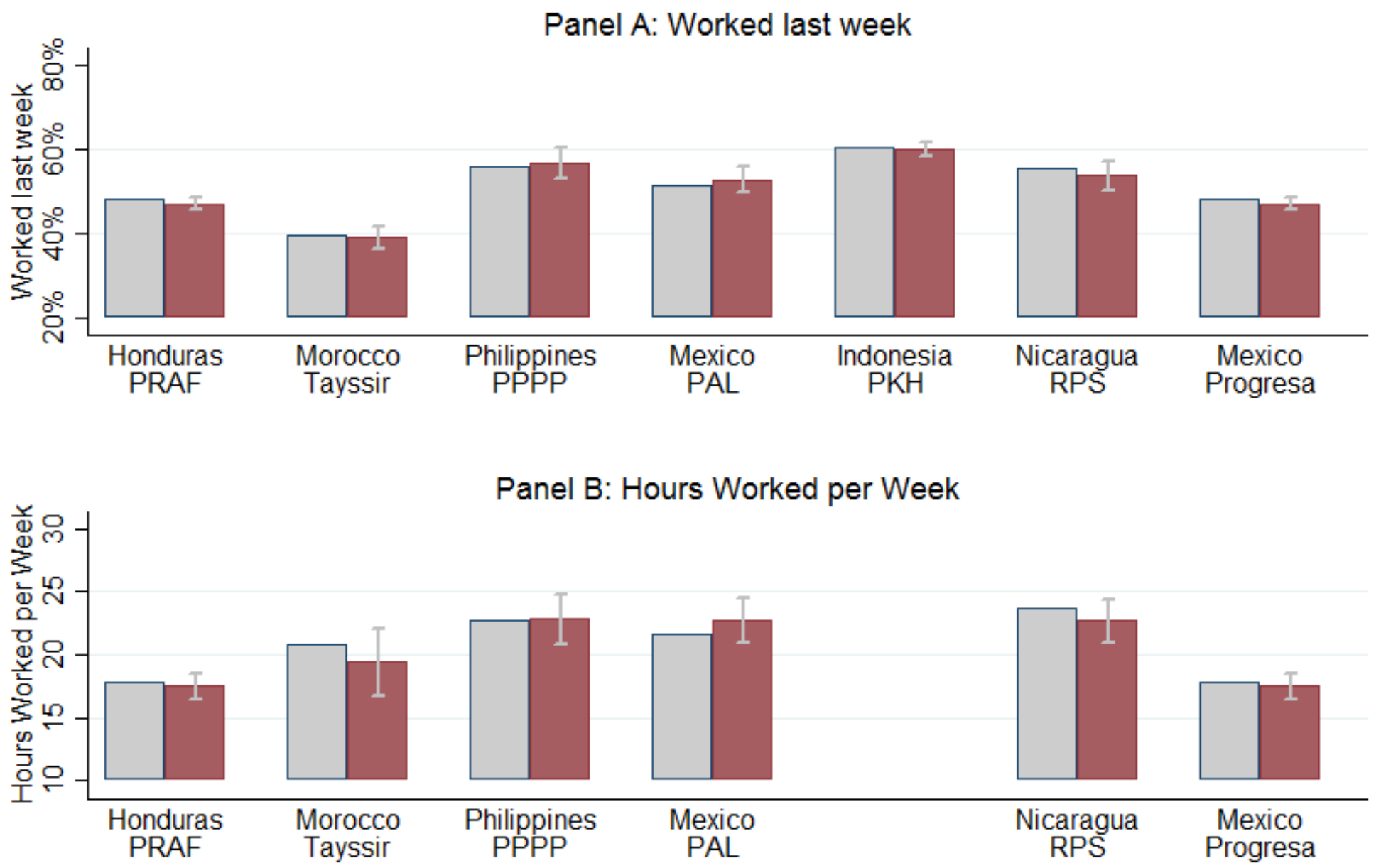

Control Treatment 
believe that households choose not to work outside the household due to fears that this form of employment could disqualify them from receiving benefits, regardless of whether this fear is rational or irrational according to program rules. Note that we do this for all programs, except Indonesia's PKH where we do not have the disaggregated data available.

In the four programs that had the least generous benefits (Columns 1-4), we find no statistically observable impacts on either type of work. We find a decrease in outside work and an associated increase in within household work in Mexico's Progresa program, but the opposite pattern holds for Nicaragua's RPS program (which has a similar transfer size). Turning to the pooled estimates across the 5 comparable evaluations, we find a 1 percentage point decrease in work within the home (significant at the 10 percent level) and no detectable effect on outside work. Thus, overall the results on the allocation of employment are consistent with the zero impact on employment and hours, and mask some heterogeneous impacts going in opposite directions across different programs.

\section{B. DISAGGREGATED BY GENDER}

As we observe large differences in baseline employment status across men and women, we next disaggregate the analysis by gender. It is not clear ex ante whether we would expect larger effects for men or women. For example, the additional income may allow a woman who previously had to work the ability to choose to stay home with the children if she prefers, or the additional income may make it possible for her to afford additional child care and actually work more. Alternatively, the literature often paints a picture of the lazy male in the developing country household, who uses transfer stipends to stay home from work and spend money on cigarettes and alcohol. 
Table 4 replicates Table 2, but disaggregating by gender, while Table 5 does the same for Table 3. The patterns are similar to the main findings above, with no effect of the transfers on either female or male work outcomes.

\section{COMPARISON WITH ASSET TRANSFER PROGRAMS}

Our analysis has focused on cash transfers programs that provide small amounts of money either monthly or quarterly to poor households. However, a policy alternative to cash transfers is an asset transfer program. This is more of a one-time intervention where the beneficiary gets the gift of a productive asset or money to buy such an asset, with the idea that they will benefit from the income stream from the asset in the future.

The labor supply effect of this program could be quite different from that of an income transfer because it is a lump sum or a lumpy asset, potentially worth much more than the amounts that the beneficiary household has access to through savings or borrowing. If it is a productive asset (e.g. livestock or tools for a business) that requires household labor-say because the labor is needed to take advantage of this capital and because of transaction cost in the labor market that prevent households from hiring labor, or if the household has labor that is underemployed for the same reasons-the presence of the asset would quite naturally encourage the household to work harder. Labor supply would also increase if the household combines the lump sum with a loan to purchase a consumer durable that complements the asset, but then needs work harder to pay down the loan.

There is now evidence on this from a number of asset transfer programs across the world. One version of the program is the so-called graduation model, developed by BRAC in Bangladesh. Under this model, households, chosen for being the poorest members of poor communities, are given an asset of their choosing (from a set of affordable assets) as well as 
some training and support, including a small income stipend for a short period of time (no more than six months). An RCT of this program by Bandiera et al. (2015) reports, "After four years, eligible women work 170 fewer hours per year in wage employment (a 26\% reduction relative to baseline) and 388 more hours in self-employment (a 92\% increase relative to baseline). Hence total annual labor supply increases by an additional 218 hours which represents an increase of 19\% relative to baseline." Another RCT by Banerjee et al. (2015) of this program in six different countries (Ethiopia, Ghana, Honduras, India, Pakistan, Peru), reports that total labor supply across the six sites went up by 10 percent of the control group mean (or about 85 hours a year), two years after the start of the program. Consistent with this, both the Bangladesh study and the multi-country study also find increases in income and consumption of commensurate magnitudes in these households.

There is also evidence from a small number of lump sum cash transfer programs. Blattman et al. (2015) carry out a randomized evaluation of a program where women in Northern Uganda most of whom had never run a business before were given a package comprised of $\$ 150$ in cash, five days of business training, and ongoing supervision. They find that hours worked per week goes up by a stunning 10 hours, and correspondingly, there is a doubling of new non-farm enterprises and a significant rise in incomes. Blattman (2014) also evaluates the Youth Opportunities Program (YOP), a government program in northern Uganda designed to help unemployed adults become self-employed artisans. The government invited young adults to form groups and prepare proposals for how they would use a grant to train in and start independent trades. Funding was randomly assigned among 535 screened, eligible applicant groups. Successful proposals received one-time unsupervised grants worth $\$ 7,500$ on average-about $\$ 382$ per group member, roughly their average annual income. After four years the treatment group had 57\% greater capital stocks, 38\% higher earnings, and 17\% more 
hours of work than did the control group.

Perhaps not surprisingly, these have a strong and clear positive effect on labor supply, in contrast with the more or less zero effect we find from the income support style cash transfer programs. However, it is very important to note two aspects of these programs. First, all of these programs combined assets (or cash for assets) with training and support, and so the evidence is not yet available as to whether supervision is needed to achieve these increases in work or just the asset transfer would be enough. Moreover, it is likely that labor supply is a complementary input to the asset; for example, a cow or goat needs to be fed and taken care of. Future research is needed to disentangle the various aspects of the programs. Second, in thinking through large-scale implementation across governments, physical assets (and in-kind transfers, in general) are often more expensive to distribute than cash. Moreover, we often observe leakages in the distribution of in-kind goods in many developing countries, with the goods never reaching program beneficiaries. New advances in technologies for distributing cash, such as mobile money, may make it easier to provide cash directly to beneficiaries with both potentially low leakage and low costs. Thus, research into understanding how large-scale physical asset distribution programs fare against these newer ways to distribute cash is also important for policy.

\section{CONCLUSION}

In recent years, there has been a large growth in safety net programs across the developing world. If anything, we might expect this trend to increase as countries become richer: Chetty and Looney (2006) show that social insurance as a fraction of GDP rises as countries get richer, suggesting an that safety nets may be increasingly important as countries grow. 
As safety nets have increased, so has the debate about whether they simply discourage work, enabling a "lazy poor." Aggregating evidence from randomized evaluations of seven cash transfer programs, we find no effects of transfers on work behavior, either for men or women. Moreover, a 2014 review of transfer programs worldwide by Evans and Popova also show no evidence-despite claims in the policy debate-that the transfers induce increases in spending on temptation goods, such alcohol and tobacco. Thus, on net, the available evidence implies cash transfer programs do not induce the "bad" behaviors that are often attributed to them in the policy space.

\section{WORKS CITED}

Akresh, Richard, Damien De Walque, and Harounan Kazianga. 2013. "Cash Transfers and Child Schooling: Evidence from a Randomized Evaluation of the Role of Conditionality." World Bank Policy Research Working Paper 6340.

Alatas, Vivi, Abhijit Banerjee, Rema Hanna, Benjamin A. Olken, and Julia Tobias. 2012. "Targeting the Poor: Evidence from a Field Experiment in Indonesia." American Economic Review 102(4): 1206-40.

Alzúa, María Laura, Guillermo Cruces, and Laura Ripani. 2013. "Welfare programs and labor supply in developing countries: experimental evidence from Latin America." Journal of Population Economics 26(4): 1255-1284.

American Institutes for Research. 2013. “Zambia’s Child Grant Program: 24 Month Impact Report.” Washington, DC.

Ashenfelter, Orley, and Mark W. Plant. 1990. "Nonparametric estimates of the labor-supply effects of negative income tax programs." Journal of Labor Economics, S396-S415.

Attanasio, Orazio, Erich Battistin, Emla Fitzsimons, and Marcos Vera-Hernandez. 2005. "How effective are conditional cash transfers? Evidence from Colombia." Institute for Fiscal Studies Briefing Note.

Baird, Sarah, Craig McIntosh, and Berk Özler. 2011. "Cash or condition? Evidence from a cash transfer experiment." Quarterly Journal of Economics, 126(4): 1709-1753.

Bandiera, Oriana, Robin Burgess, Narayan Das, Selim Gulesci, Imran Rasul, and Munshi Sulaiman. 2013. "Can entrepreneurship programs transform the economic lives of the poor?" IZA Discussion Papers 7386.

Banerjee, Abhijit V., Esther Duflo, Nathanael Goldberg, Dean Karlan, Robert Osei, William Parienté, 
Jeremy Shapiro, Bram Thuysbaert, and Christopher Udry. 2015. "A Multi-faceted Program Causes Lasting Progress for the Very Poor: Evidence from Six Countries.” Science, 348(6236): 1260799.

Barrera-Osorio, Felipe, Marianne Bertrand, Leigh L. Linden, and Francisco Perez-Calle. 2011. "Improving the Design of Conditional Transfer Programs: Evidence from a Randomized Education Experiment in Colombia." American Economic Journal: Applied Economics, 3(2): 167-95.

Benhassine, Najy, Florencia Devoto, Esther Duflo, Pascaline Dupas, and Victor Pouliquen. 2015. "Turning a Shove into a Nudge? A "Labeled Cash Transfer" for Education." American Economic Journal: Economic Policy, 7(3): 86-125.

Blattman, Christopher, Nathan Fiala, and Sebastian Martinez. 2014. "Generating skilled employment in developing countries: Experimental evidence from Uganda." Quarterly Journal of Economics, 129(2): 697-752.

Blattman, Christopher, Eric Green, Julian Jamison, and Jeannie Annan. 2015. "The returns to microenterprise support among the ultra-poor: A field experiment in post-war Uganda" forthcoming in American Economic Journal: Applied Economics.

Chaudhury, Nazmul, Jed Friedman, and Junko Onishi. 2013. "Philippines conditional cash transfer program impact evaluation 2012." Manila: World Bank Report Number 75533-PH.

Chetty, Raj, and Adam Looney. 2007. "Income risk and the benefits of social insurance: Evidence from Indonesia and the United States." In Fiscal Policy and Management in East Asia, NBER-EASE, Volume 16, 99-121. Chicago: University of Chicago Press.

Covarrubias, Katia, Benjamin Davis, and Paul Winters. 2012. "From protection to production: productive impacts of the Malawi social cash transfer scheme."Journal of Development Effectiveness 4(1): 50-77.

Edmonds, Eric V., and Norbert Schady. 2012. "Poverty Alleviation and Child Labor." American Economic Journal: Economic Policy, 4(4): 100-124.

Evans, David, Stephanie Hausladen, Katrina Kosec, and Natasha Reese. 2014. Community-Based Conditional Cash Transfers in Tanzania: Results from a Randomized Trial. Washington, DC: World Bank Publications.

Fiszbein, Ariel, Norbert Rüdiger Schady, and Francisco HG Ferreira. 2009. Conditional cash transfers: reducing present and future poverty. World Bank Publications.

Galiani, Sebastian, and Patrick J. McEwan. 2013. "The heterogeneous impact of conditional cash transfers." Journal of Public Economics 103: 85-96.

Gentilini, Ugo, Maddalena Honorati, and Ruslan Yemtsov. 2014. "The state of social safety nets 2014." Washington, DC : World Bank Group.

Gertler, Paul. 2000. "Final Report: The Impact of Progresa on Health." International Food Policy Research Institute (IFPRI): Food Consumption and Nutrition Division.

Gertler, Paul. 2004. "Do conditional cash transfers improve child health? Evidence from 
PROGRESA's control randomized experiment." American Economic Review 94(2): 336-341.

Gilligan, Daniel O., and Shalini Roy. 2013. "Resources, stimulation, and cognition: How transfer programs and preschool shape cognitive development in Uganda." Washington, DC: International Food Policy Research Institute (IFPRI).

Glewwe, Paul, and Pedro Olinto. 2004. "Evaluating the Impact of Conditional Cash Transfers on Schooling: An Experimental Analysis of Honduras' PRAF Program." University of Minnesota Unpublished Manuscript.

Haushofer, Johannes, and Jeremy Shapiro. 2013. "Household response to income changes: Evidence from an unconditional cash transfer program in Kenya." Massachusetts Institute of Technology.

Imbens, Guido W., Donald B. Rubin, and Bruce I. Sacerdote. 2001. "Estimating the effect of unearned income on labor earnings, savings, and consumption: Evidence from a survey of lottery players." American Economic Review: 778-794.

Maluccio, John, and Rafael Flores. 2005. "Impact Evaluation of a Conditional Cash Transfer Program the Nicaraguan Red de Protección Social.” Washington, DC: International Food Policy Research Institute (IFPRI) Report 141.

Macours, Karen, Norbert Schady, and Renos Vakis. 2012. "Cash Transfers, Behavioral Changes, and Cognitive Development in Early Childhood: Evidence from a Randomized Experiment." American Economic Journal: Applied Economics, 4(2): 247-73.

Parker, Susan W., and Emmanuel Skoufias. 2000. "The Impact of PROGRESA on Work, Leisure, and Time Allocation.” Washington, DC: International Food Policy Research Institute (IFPRI) Report, October.

Schady, Norbert, and Maria C. Araujo. 2008. "Cash Transfers, Conditions, and School Enrollment in Ecuador." Economía 8(2): 43-70.

Schultz, Paul. 2004. "School subsidies for the poor: Evaluating the Mexican Progresa poverty program.” Journal of Development Economics 74 (1): 199-250.

Skoufias, Emmanuel, and Vincenzo Di Maro. 2008. "Conditional cash transfers, adult work incentives, and poverty." The Journal of Development Studies 44(7): 935-960.

Skoufias, Emmanuel, Mishel Unar, and Teresa Gonzalez de Cossio. 2013. "The poverty impacts of cash and in-kind transfers: experimental evidence from rural Mexico." Journal of Development Effectiveness 5(4): 401-429.

World Bank Office Jakarta. 2011. "Main findings from the impact evaluation of Indonesia's pilot household conditional cash transfer program." World Bank. 
Table 1: Descriptive Statistics for Non-Program Areas

\begin{tabular}{|c|c|c|c|c|c|c|c|}
\hline & $\begin{array}{c}\text { Honduras } \\
\text { PRAF } \\
(1) \\
\end{array}$ & $\begin{array}{c}\text { Morocco } \\
\text { Tayssir } \\
(2) \\
\end{array}$ & $\begin{array}{c}\text { Phillipines } \\
\text { PPPP } \\
(3)\end{array}$ & $\begin{array}{c}\text { Mexico } \\
\text { PAL } \\
(4)\end{array}$ & $\begin{array}{c}\text { Indonesia } \\
\text { PKH } \\
(5) \\
\end{array}$ & $\begin{array}{c}\text { Nicaragua } \\
\text { RPS } \\
(6) \\
\end{array}$ & $\begin{array}{c}\text { Mexico } \\
\text { Progresa } \\
(7) \\
\end{array}$ \\
\hline \multicolumn{8}{|c|}{ Panel A: Work Outcomes } \\
\hline Worked last week & 0.59 & 0.40 & 0.56 & 0.52 & 0.61 & 0.55 & 0.48 \\
\hline Hours/Week & 19.80 & 20.87 & 22.73 & 21.65 & & 23.63 & 17.87 \\
\hline Worked for Self/Family & 0.42 & 0.19 & 0.26 & 0.17 & & 0.26 & 0.07 \\
\hline Worked Out of $\mathrm{HH}$ & 0.26 & 0.20 & 0.29 & 0.27 & & 0.29 & 0.38 \\
\hline Observations & 4,171 & 2,757 & 2,293 & 3,609 & 20,246 & 4,183 & 53,226 \\
\hline \multicolumn{8}{|c|}{ Panel B: Work Outcomes for Men } \\
\hline Worked last week & 0.90 & 0.81 & 0.72 & 0.80 & 0.82 & 0.93 & 0.86 \\
\hline Hours/Week & 31.70 & 34.31 & 29.51 & 35.86 & & 39.51 & 34.56 \\
\hline Worked for Self/Family & 0.67 & 0.41 & 0.31 & 0.30 & & 0.46 & 0.10 \\
\hline Worked Out of HH & 0.38 & 0.40 & 0.39 & 0.46 & & 0.47 & 0.70 \\
\hline Observations & 2,132 & 1,272 & 1,215 & 1,668 & 10,198 & 2,131 & 25,850 \\
\hline \multicolumn{8}{|c|}{ Panel C: Work Outcomes for Women } \\
\hline Worked last week & 0.27 & 0.05 & 0.38 & 0.27 & 0.39 & 0.16 & 0.12 \\
\hline Hours/Week & 7.37 & 9.50 & 15.09 & 9.67 & & 6.96 & 3.67 \\
\hline Worked for Self/Family & 0.16 & 0.01 & 0.19 & 0.06 & & 0.05 & 0.03 \\
\hline Worked Out of $\mathrm{HH}$ & 0.13 & 0.04 & 0.18 & 0.10 & & 0.11 & 0.08 \\
\hline Observations & 2,039 & 1,483 & 1,078 & 1,941 & 10,048 & 2,052 & 27,305 \\
\hline
\end{tabular}

Notes: This table reports descriptive statistics from the control group at endline. Panels A, B and C restrict the sample respectively to all adults, men and women, between 16 and 65 years old. The binary work indicator is equal to 1 if the respondent reported working during the last week (last 30 days for Morocco Tayssir); the other work variables are reported for the same time frame. 
Table 2: Experimental Estimates of the Impact of Cash Transfer Programs on Work Outcomes

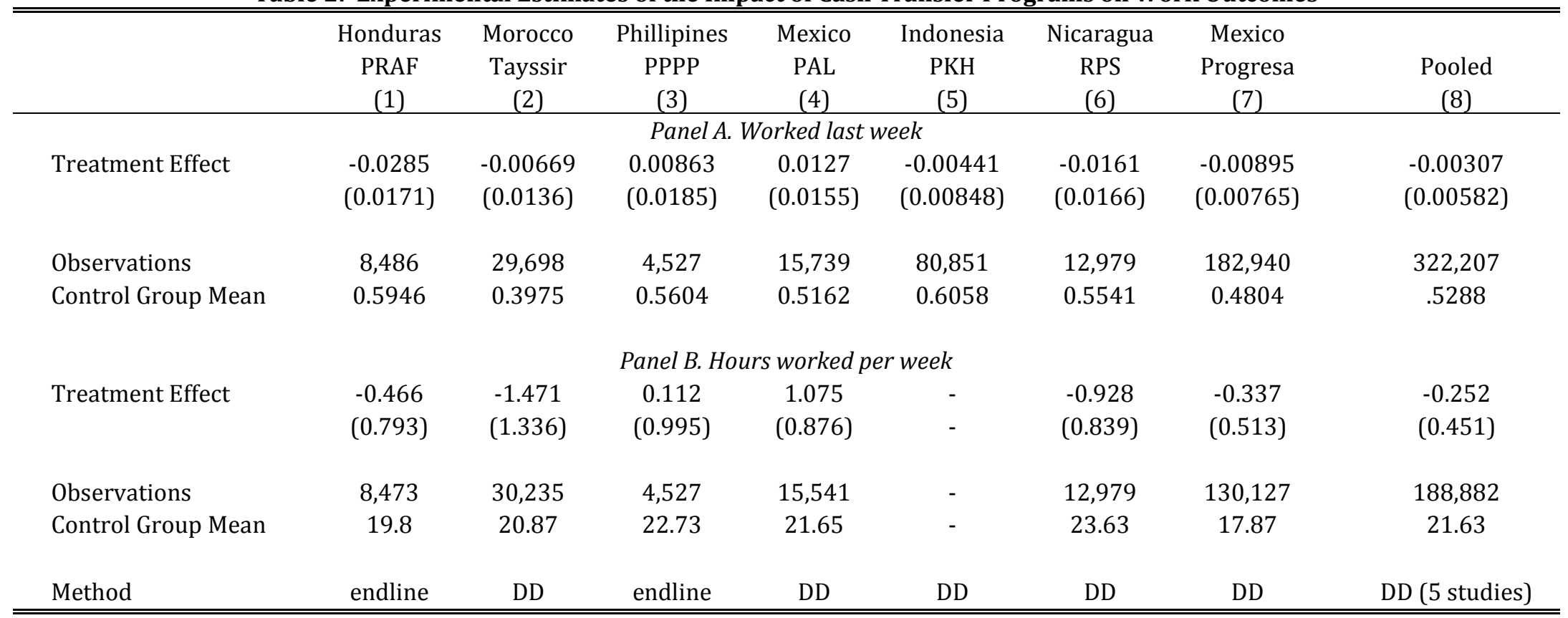

Notes: This table reports regression results of the impact of cash transfers on a dummy for working (panel A) and on the number of hours worked per week (panel B). Columns 1-7 report results from each study separately, and column (8) reports a pooled regression over 5 studies (Honduras PRAF and Philippines PPP are excluded). The treatment effect is the coefficient on Treatment x Follow-up for differences-indifferences (DD), and the coefficient on Treatment otherwise. Controls are age, age squared, years of education, marital status dummies (single, married or with partner, divorced or separated, and widow), household size, and survey wave fixed effects, as well as dummies for missing values for each control variable. Columns 1,2,3,5,6 include randomization strata fixed effects, columns 4 and 7 include randomization unit (village) fixed effects, and Column 8 contains the fixed effects from each study and all controls interacted with study dummies. The sample is all adults between 16 and 65 years old, excluding domestic workers. Standard errors clustered at the randomization unit level are reported in parentheses. ${ }^{* * *} \mathrm{p}<0.01,{ }^{* *} \mathrm{p}<0.05,{ }^{*} \mathrm{p}<0.1$ 
Table 3: Experimental Estimates of the Impact of Cash Transfer Programs on Household and Private Market Work Outcomes

\begin{tabular}{|c|c|c|c|c|c|c|c|c|}
\hline & $\begin{array}{c}\text { Honduras } \\
\text { PRAF } \\
(1)\end{array}$ & $\begin{array}{c}\text { Morocco } \\
\text { Tayssir } \\
\text { (2) }\end{array}$ & $\begin{array}{c}\text { Phillipines } \\
\text { PPPP } \\
\text { (3) }\end{array}$ & $\begin{array}{c}\text { Mexico } \\
\text { PAL } \\
(4)\end{array}$ & $\begin{array}{c}\text { Indonesia } \\
\text { PKH } \\
(5)\end{array}$ & $\begin{array}{c}\text { Nicaragua } \\
\text { RPS } \\
(6)\end{array}$ & $\begin{array}{c}\text { Mexico } \\
\text { Progresa } \\
(7)\end{array}$ & $\begin{array}{l}\text { Pooled } \\
(8)\end{array}$ \\
\hline \multicolumn{9}{|c|}{ Panel A. Worked in household } \\
\hline Treatment Effect & $\begin{array}{c}-0.0333 \\
(0.0267)\end{array}$ & $\begin{array}{l}-0.00175 \\
(0.0170)\end{array}$ & $\begin{array}{c}0.0292 \\
(0.0207)\end{array}$ & $\begin{array}{c}-0.0156 \\
(0.0178)\end{array}$ & - & $\begin{array}{l}-0.0450 * \\
(0.0235)\end{array}$ & $\begin{array}{c}0.0191 * \\
(0.0103)\end{array}$ & $\begin{array}{c}-0.0119 * \\
(0.00713)\end{array}$ \\
\hline Observations & 8,486 & 29,698 & 4,527 & 15,739 & - & 12,979 & 182,533 & 321,800 \\
\hline Control Group Mean & .257 & .2031 & .2904 & .2671 & - & .2937 & .3835 & .2437 \\
\hline \multicolumn{9}{|c|}{ Panel B. Worked outside the household } \\
\hline Treatment Effect & $\begin{array}{c}0.0213 \\
(0.0223)\end{array}$ & $\begin{array}{l}-0.00493 \\
(0.0136)\end{array}$ & $\begin{array}{c}-0.0200 \\
(0.0213)\end{array}$ & $\begin{array}{l}0.00602 \\
(0.0167)\end{array}$ & - & $\begin{array}{l}0.0289 * * \\
(0.0128)\end{array}$ & $\begin{array}{l}-0.0235^{* *} \\
(0.00957)\end{array}$ & $\begin{array}{c}0.00539 \\
(0.00574)\end{array}$ \\
\hline Observations & 8,483 & 29,698 & 4,527 & 15,739 & - & 12,979 & 182,533 & 321,800 \\
\hline Control Group Mean & 0.4213 & 0.1944 & 0.2569 & 0.1693 & - & 0.2604 & 0.0664 & .1401 \\
\hline Method & endline & DD & endline & DD & & DD & DD & DD (5 studies) \\
\hline
\end{tabular}

Notes: This table reports regression results of the impact of cash transfers on a dummy for working for self/family (panel A) and on a dummy for working outside the household (panel B). See Table 2 notes for specification details. ${ }^{* * *} \mathrm{p}<0.01,{ }^{* *} \mathrm{p}<0.05,{ }^{*} \mathrm{p}<0.1$ 
Table 4: Experimental Estimates of the Impact of Cash Transfer Programs on Work Outcomes, by Gender

\begin{tabular}{|c|c|c|c|c|c|c|c|c|}
\hline & $\begin{array}{l}\text { Honduras } \\
\text { PRAF } \\
(1)\end{array}$ & $\begin{array}{l}\text { Morocco } \\
\text { Tayssir } \\
\text { (2) }\end{array}$ & $\begin{array}{c}\text { Phillipines } \\
\text { PPPP } \\
\text { (3) }\end{array}$ & $\begin{array}{c}\text { Mexico } \\
\text { PAL } \\
(4)\end{array}$ & $\begin{array}{c}\text { Indonesia } \\
\text { PKH } \\
(5)\end{array}$ & $\begin{array}{c}\text { Nicaragua } \\
\text { RPS } \\
(6)\end{array}$ & $\begin{array}{c}\text { Mexico } \\
\text { Progresa } \\
(7)\end{array}$ & $\begin{array}{c}\text { Pooled } \\
\text { (8) }\end{array}$ \\
\hline \multicolumn{9}{|c|}{ Panel A. Worked last week - MEN } \\
\hline \multirow[t]{2}{*}{ Treatment Effect } & 0.0118 & -0.00519 & 0.0312 & 0.00940 & -0.00786 & -0.000454 & -0.00236 & -0.000540 \\
\hline & $(0.0133)$ & $(0.0173)$ & $(0.0199)$ & $(0.0222)$ & $(0.00741)$ & $(0.0140)$ & $(0.00745)$ & $(0.00670)$ \\
\hline Observations & 4,279 & 13,820 & 2,377 & 7,378 & 40,560 & 6,632 & 89,621 & 158,011 \\
\hline Control Group Mean & .9048 & .8052 & .716 & .8046 & .8208 & .9289 & .86 & .8602 \\
\hline \multicolumn{9}{|c|}{ Panel B. Worked last week - WOMEN } \\
\hline \multirow[t]{2}{*}{ Treatment Effect } & -0.0516 & 0.000361 & -0.0120 & 0.0233 & $6.60 \mathrm{e}-05$ & -0.0237 & -0.0174 & -0.00380 \\
\hline & $(0.0317)$ & $(0.0159)$ & $(0.0271)$ & $(0.0222)$ & $(0.0141)$ & $(0.0262)$ & $(0.0118)$ & $(0.00875)$ \\
\hline Observations & 4,207 & 15,878 & 2,150 & 8,361 & 40,291 & 6,347 & 93,104 & 163,981 \\
\hline Control Group Mean & .2702 & .0511 & .385 & .2684 & .3875 & .1608 & .1212 & .2089 \\
\hline \multicolumn{9}{|c|}{ Panel C. Hours worked per week - MEN } \\
\hline \multirow[t]{2}{*}{ Treatment Effect } & 1.180 & -1.146 & 1.115 & 1.634 & - & -0.392 & 0.374 & 0.243 \\
\hline & $(1.007)$ & $(1.567)$ & $(1.234)$ & $(1.515)$ & - & $(1.216)$ & $(0.618)$ & $(0.660)$ \\
\hline Observations & 4,269 & 14,073 & 2,377 & 7,233 & - & 6,632 & 61,327 & 89,265 \\
\hline Control Group Mean & 31.7 & 34.31 & 29.51 & 35.86 & - & 39.51 & 34.56 & 37.12 \\
\hline \multicolumn{9}{|c|}{ Panel D. Hours worked per week - WOMEN } \\
\hline \multirow[t]{2}{*}{ Treatment Effect } & -1.486 & -1.544 & -0.872 & 1.071 & - & -1.084 & -0.834 & -0.539 \\
\hline & $(1.114)$ & $(1.558)$ & $(1.295)$ & $(0.874)$ & - & $(0.939)$ & $(0.625)$ & $(0.523)$ \\
\hline Observations & 4,204 & 16,158 & 2,150 & 8,308 & - & 6,347 & 68,610 & 99,423 \\
\hline Control Group Mean & 7.371 & 9.496 & 15.09 & 9.667 & - & 6.958 & 3.665 & 7.252 \\
\hline Method & endline & DD & endline & DD & DD & DD & DD & DD (5 studies) \\
\hline
\end{tabular}

Notes: This table replicates Table 2 , by gender. See Table 2 for specification details. ${ }^{* * *} \mathrm{p}<0.01,{ }^{* *} \mathrm{p}<0.05,{ }^{*} \mathrm{p}<0.1$ 
Table 5: Experimental Estimates of the Impact of Cash Transfer Programs on Household and Private Market Work, by Gender

\begin{tabular}{|c|c|c|c|c|c|c|c|c|}
\hline & $\begin{array}{c}\text { Honduras } \\
\text { PRAF } \\
\text { (1) }\end{array}$ & $\begin{array}{c}\text { Morocco } \\
\text { Tayssir } \\
(2)\end{array}$ & $\begin{array}{c}\text { Phillipines } \\
\text { PPPP } \\
(3)\end{array}$ & $\begin{array}{c}\text { Mexico } \\
\text { PAL } \\
(4)\end{array}$ & $\begin{array}{c}\text { Indonesia } \\
\text { PKH } \\
(5)\end{array}$ & $\begin{array}{c}\text { Nicaragua } \\
\text { RPS } \\
(6) \\
\end{array}$ & $\begin{array}{c}\text { Mexico } \\
\text { Progresa } \\
(7)\end{array}$ & $\begin{array}{c}\text { Pooled } \\
(8)\end{array}$ \\
\hline \multicolumn{9}{|c|}{ Panel A. Worked in household - MEN } \\
\hline \multirow[t]{2}{*}{ Treatment Effect } & -0.0170 & 0.00561 & 0.0326 & -0.0160 & - & $-0.0597^{*}$ & $0.0378^{* *}$ & -0.0135 \\
\hline & $(0.0342)$ & $(0.0293)$ & $(0.0288)$ & $(0.0334)$ & - & $(0.0321)$ & $(0.0190)$ & $(0.0118)$ \\
\hline Observations & 4,279 & 13,820 & 2,377 & 7,378 & - & 6,632 & 89,423 & 157,813 \\
\hline Control Group Mean & .3818 & .3997 & .3852 & .4592 & - & .4701 & .7048 & .4201 \\
\hline \multicolumn{9}{|c|}{ Panel B. Worked in household - WOMEN } \\
\hline \multirow[t]{2}{*}{ Treatment Effect } & $-0.0441^{*}$ & -0.00122 & 0.0267 & -0.00928 & - & -0.0238 & -0.000795 & -0.00871 \\
\hline & $(0.0257)$ & $(0.0141)$ & $(0.0209)$ & $(0.0133)$ & - & $(0.0211)$ & $(0.00586)$ & $(0.00564)$ \\
\hline Observations & 4,207 & 15,878 & 2,150 & 8,361 & - & 6,347 & 92,895 & 163,772 \\
\hline Control Group Mean & .1265 & .0361 & .1837 & .102 & - & .1085 & .0795 & .0732 \\
\hline \multicolumn{9}{|c|}{ Panel C. Worked outside the household - MEN } \\
\hline \multirow[t]{2}{*}{ Treatment Effect } & 0.0643 & -0.0108 & 0.00148 & 0.0136 & - & $0.0592^{* *}$ & $-0.0303^{* *}$ & 0.0138 \\
\hline & $(0.0396)$ & $(0.0263)$ & $(0.0284)$ & $(0.0327)$ & - & $(0.0248)$ & $(0.0139)$ & $(0.0107)$ \\
\hline Observations & 4,276 & 13,820 & 2,377 & 7,378 & - & 6,632 & 89,423 & 157,813 \\
\hline Control Group Mean & 6748 & .4056 & .3136 & .2998 & - & .4588 & .1018 & .2486 \\
\hline \multicolumn{9}{|c|}{ Panel D. Worked outside the household - WOMEN } \\
\hline \multirow[t]{2}{*}{ Treatment Effect } & -0.00699 & 0.00158 & $-0.0413^{*}$ & 0.000788 & - & 0.000104 & $-0.0173^{*}$ & -0.00310 \\
\hline & $(0.0191)$ & $(0.00574)$ & $(0.0220)$ & $(0.0158)$ & - & $(0.0122)$ & $(0.0102)$ & $(0.00492)$ \\
\hline Observations & 4,207 & 15,878 & 2,150 & 8,361 & - & 6,347 & 92,895 & 163,772 \\
\hline Control Group Mean & .1564 & .0149 & .1929 & .0572 & - & .0522 & .0328 & .0354 \\
\hline Method & endline & DD & endline & DD & & DD & DD & DD (5 studies) \\
\hline
\end{tabular}

Notes: This table replicates Table 3, by gender. See Table 2 for specification details. ${ }^{* * *} \mathrm{p}<0.01,{ }^{* *} \mathrm{p}<0.05,{ }^{*} \mathrm{p}<0.1$ 